\title{
Incidence of Bovine Clinical Mastitis Caused by Escherichia coli
}

\author{
V. Manasa ${ }^{1 *}$, T. Venkata Sai Kumar ${ }^{1}$, T. Prasada Rao ${ }^{1}$, \\ K. Aswani Kumar ${ }^{2}$ and K. Sireesha ${ }^{3}$ \\ ${ }^{1}$ Department of Veterinary Biochemistry, SVVU, College of Veterinary Science, \\ Proddatur, AP-516360, India \\ ${ }^{2}$ Department of Veterinary Biochemistry, SVVU, NTR College of Veterinary Sciences, \\ Gannavaram, AP, India \\ ${ }^{3}$ Department of Animal Husbandry, Andhra Pradesh, India \\ *Corresponding author
}

\begin{abstract}
A B S T R A C T
\section{Keywords}

Bovine mastitis, $E$. coli, Polymerase Chain Reaction, Incidence, Clinical mastitis

Article Info

Accepted:

12 April 2019

Available Online:

10 May 2019

Bovine mastitis cause severe economic losses resulting from reduced milk production, treatment cost, increased labour, milk withheld following treatment and increased cost of veterinary services. Escherichia coli is one of the major environmental pathogen associated with clinical mastitis. Therefore the present study was done to know the incidence of clinical mastitis caused by E. coli in the Proddatur region of Andhra Pradesh by means of culture and confirmation by Polymerase Chain reaction (PCR). Out of 78 clinical mastitis milk samples obtained from various semi-organized private farms, a very high incidence rate of bovine clinical mastitis caused by $E$. coli has been reported which was found to be $41 \%$ as identified by isolation of gram negative bacteria on basic media, followed by selective differentiation of $E$. coli using eosine methylene blue agar and further confirmation by PCR. This study suggests an important need for the adequate milking procedures, maintenance of proper sanitation, regular screening for the early detection of sub-clinical mastitis cases, good udder health practices including pre- and post dipping for the prevention and control of mastitis due to E. coli.
\end{abstract}

\section{Introduction}

Mastitis is a complex, multifactorial disease and continues to be the most costly disease of dairy animals. Bovine mastitis results in a great deal of economic losses, mostly because of the reduction of milk yield, decreased milk quality, and higher production costs, medication costs, discarded milk during and shortly after treatment, loss of milking days, reduced milk price, increased labour and increased recruitment costs due to culling
(Seegers et al., 2003 and Cremonesi et al., 2006). As such, the incidence of bovine mastitis depends on exposure to pathogens, effectiveness of udder defence mechanisms and presence of environmental risk factors, as well as interactions between these factors (Suriyasathaporn et al., 2000; Oviedo-Boyso et al., 2007).

Microorganisms causing mastitis are of two types based upon their primary reservoir and mode of transmission- Environmental 
pathogens which include coliform species like E.coli, Klebsiella and species of Streptococci. These arise from the environment in which the cow lives, when teats are exposed to mud, manure and dirty bedding materials; Contagious pathogens like $S$. aureus, Streptococcus agalactiae which are transmitted among cows by contact with infected milk (Cremonesi et al., 2006). In Asia, major mastitis causing organisms are Staphylococcus aureus, Streptococci, E. coli, Corynebacterium Sp. and Klebsiella Sp. (Sharma et al., 2012).

Clinical mastitis is recognized by abnormal milk (visible clots in milk, change in the colour of the milk) gland swelling and /or systemic illness. Clinical mastitis can be peracute, acute, subacute and chronic, caused by coliforms like Escherichia coli, Klebsiella pneumoniae, K. oxytoca etc. The reduction in milk production attributed to clinical mastitis could be 30.0 percent of the total losses (Philpot and Nickerson, 1991 and Philip et al., 1993). E. coli is reported to be one of the commonest pathogens in environmental mastitis resulting in sudden onset of fever, loss of appetite, diarrhea, toxaemia and the infected quarter shows swelling, pain with discharge of watery or bloody milk. Necrosis of the mammary epithelium occurs during severe, naturally occurring clinical E.coli mastitis, as well as during severe experimental E. coli mastitis (Bradley and Green, 2001). Early identification of the prevalence and distribution of causative pathogens is one of the important prerequisite to effectively prevent diseases and to guide treatment. So far, the incidence of $E$. coli in bovine clinical mastitis in Proddatur region of Andhra Pradesh is not known. Therefore, the present study was conducted to determine the incidence of $E$. coli in bovine clinical mastitis in Proddatur region of Andhra Pradesh by means of isolation and identification and confirmation by Polymerase Chain Reaction.

\section{Materials and Methods}

\section{Sample collection}

A total of 78 clinical mastitis milk samples (31 Jersey cross bred cows, 28 Graded Murrah buffaloes and 19 Holstein Fresian cross bred cows) were collected from various semi-organized private farms maintained in Proddatur town and villages nearby. Teats were wiped with $70 \%$ alcohol before collecting the samples. One or two streams of milk were discarded before collecting samples from the infected quarter. The collected samples were transported in ice cold condition and stored at $4{ }^{\circ} \mathrm{C}$ until further processing.

\section{Isolation and identification of bacteria}

Samples were mixed well and two or three loopful of milk was streaked on to Mueller Hinton agar, incubated at $37^{\circ} \mathrm{C}$ for $24-48 \mathrm{hrs}$. The cultured organisms were then subjected for bacteriological analysis. The gram negative bacterial colonies from the isolates were then identified by Gram's staining technique as recommended by the manufacturer's kit (Himedia, Mumbai). The gram negative isolates were then streaked on to EMB agar for the identification of E.coli.

\section{Extraction of bacterial DNA}

The sample DNA was extracted from the gram negative isolates of clinical mastitic cases by using polyethylene glycol (PEG) as recommended by PioChomczynski and Michal Rymaszewski et al., 2006 with slight modifications. Colonies from the isolates were transferred to $100 \mu \mathrm{l}$ of nuclease free water and then mixed with $900 \mu \mathrm{l}$ of PEG reagent. The mixture was vortexed for 2-3 min, incubated in water bath at $90^{\circ} \mathrm{C}$ for 15 min. and then centrifuged at $12,000 \mathrm{rpm}$ for $10 \mathrm{~min}$. The lysate was then stored at $-80^{\circ} \mathrm{C}$ 
and used as the template for Polymerase Chain Reaction (PCR).

\section{PCR for E.coli}

PCR assay targeting an 884 bp region of E.coli chromosomes' usp A gene (Chen and Griffiths, 1998) was performed using the primer set; forward 5' CCGATACGCTGCCAATCAGT-3, and reverse 5'- ACGCAGACCGTAGGCCAGAT3'. A $25 \mu \mathrm{l}$ of PCR reaction mix was prepared using $12.5 \mu$ l of Dream taq green PCR master mix (Thermo Scientific), $1 \mu \mathrm{l}$ of forward primer, $1 \mu \mathrm{l}$ of reverse primer, $5 \mu \mathrm{l}$ of template and $5.5 \mu \mathrm{l}$ of nuclease free water. Amplification was carried out as follows: an initial denaturation of $95^{\circ} \mathrm{C}$ for 4 minutes; 30 cycles of $95^{\circ} \mathrm{C}$ for $45 \mathrm{sec}, 55^{\circ} \mathrm{C}$ for $45 \mathrm{sec}$ and $72^{\circ} \mathrm{C}$ for $45 \mathrm{sec}$ and a final extension step at $72^{\circ} \mathrm{C}$ for $6 \mathrm{~min}$.

\section{Agarose gel electrophoresis}

The DNA fragments were stained with ethidium bromide and were visualized using Chemi documentation system from Syngene, Biocon, U.S.A. The size of the amplified product was compared by the use of $100 \mathrm{bp}$ DNA ladder, Amresco.

\section{Results and Discussion}

Isolation and identification of causative pathogens of bovine mastitis by the use of specific media for growth and culture is still considered to be the gold standard (Radostits et al., 2000). However due to the appearance of false positive results and associated less sensitive and efficient results with the use of EMB agar for the detection of E.coli from various kinds of biological and environmental samples, use of modified media like Hicrome E.coli agar and further confirmation by using molecular methods like PCR has been recommended by various researchers (Antony et al., 2016; Islam et al., 2014). All the clinical bovine mastitis milk samples were used for the isolation and identification of gram negative bacteria using Mueller Hinton agar. Out of 78 clinical mastitis milk samples collected from jersey cross bred cows (31), graded Murrah buffaloes (28) and HF cross (19), $41 \%(32 / 78)$ of the bacterial isolates were found to be gram negative. Details are being provided in table 1 . The incidence of bovine clinical mastitis caused by gram negative bacteria was found to be highest in graded Murrah buffaloes (46\%), followed by Jersey cross bred cows (39\%) and HF cross (37\%).Among the Gram-negative bacterial etiological agents of bovine mastitis, the major group includes coliform bacteria (Escherichia coli, Enterobacter, Klebsiella), Pseudomonas and Serratia (Samanta 2013). Across the farms, E. coli tends to be the most important cause of these gram-negative infections associated with bovine mastitis. However, more precise investigation of individual farms revealed a farm-specific infection pattern where a single gramnegative bacterial species predominates. Several farms with a predominance of other gram-negative intra mammary infections (IMIs) were observed in individual dairy farm with $K$. pneumoniae, $S$. marcescens, and Enterobacter cloacae. Further, association of the host immune response pattern with the clinical and subclinical presentations of IMIs due to the different gram-negative organisms was identified (Schukken et al., 2012).

In our study, out of the 32 gram negative clinical isolates of bovine mastitis, $41 \%$ (13/32) of the bacteria were found to be E.coli as identified on EMB agar with the characteristic smooth, circular, black colour colonies with green metallic sheen (Figure 1) and further confirmation by PCR (Figure 2). The highest incidence of E.coli in bovine mastitis was identified in jersey cross breds (50\%) followed by graded Murrah buffaloes 
(39\%) and HF cross (29\%). In contrary to the present study, a much lower prevalence rate of E.coli in bovine mastitis was reported by various researchers. The prevalence of E.coli in clinical bovine clinical mastitis was found to be 20\% (Mahmoud et al., 2015). The prevalence of E.coli in sub-clinical mastitis was found to be $4.5 \%$ (Vasquez-Garcia et al., 2017). The prevalence of E.coli in bovine mastitis in Meerut was found to be $21.3 \%$ (Verma et al., 2018). Experimental and field observations would suggest that among the gram-negative bacterial causes of mastitis, Klebsiella spp are causing the most severe cases, closely followed by E. coli and then much less clinical severity is observed in Serratia spp and Enterobacter spp cases (Schukken et al., 2012).

The exotic breeds like Jersey were found to be more susceptible to bovine mastitis than indigenous breeds (Iqbal and Siddique, 1999). Dutta et al., 1990 also reported that the risk ratio of developing mastitis in Jersey was approximately two times higher than indigenous breeds. Whereas, Rahman et al., 2009 reported the highest prevalence of mastitis in HF followed by Jersey and the least in indigenous breed. Similarly Biffa $e t$ al., 2005 reported that HF cows are affected at higher rate $(56.5 \%)$ compared with local zebu $(30.9 \%)$ and Jersey cows (28.9\%). The difference in breed-wise prevalence of mastitis may be due to the inheritance characters, immunity of the individual breeds, and also habituation of cows to the climatic conditions.
The incidence of clinical mastitis in Holstein Friesian and jersey cows of Dharwad district of Karnataka was found to be $13.2 \%$ and $10.1 \%$ respectively. Breed of the cow and environmental conditions were found to be the most important factors associated with clinical bovine mastitis (Kurjogi and Kaliwal 2014). According to Litwinczuk and Brodziak (2015), a higher incidence of bovine mastitis was observed in Holstein Friesian breed. Polymorphism of bovine leukocyte antigen (BoLA) and lactoferrin genes were found to be associated with the susceptibility of cows to mastitis.

Therefore, marker assisted selection (MAS) of cross bred cows resistant to mastitis can be followed in the selection process of animals while purchase. Further, deficiency of selenium, vitamin $\mathrm{A}$ and vitamin $\mathrm{E}$ in the ration was found to contribute to the increase in the incidence of mastitis in dairy cows.

Studies also reported that there is increase in the trend of E.coli isolated from bovine mastitis to produce biofilm which inturn contributes to the aggravation and recurrence of clinical mastitis under conditions of low glucose availability $(0.5-1.5 \%)$ or with either an acidic (5.5) or alkaline (8.5) pH (Costa et al., 2014). Also researchers have demonstrated that sub-inhibitory concentrations of enrofloxacin $(0.0125$ $\mathrm{mg} / \mathrm{ml}$ ) were able to induce biofilm formation in in vitro in the E.coli isolated from bovine mastitis (Costa et al., 2012).

Table.1 Incidence of bovine clinical mastitis caused by E.coli

\begin{tabular}{|c|c|c|c|c|c|}
\hline \multirow[t]{2}{*}{ Source } & \multirow{2}{*}{$\begin{array}{l}\text { No. of } \\
\text { samples } \\
\text { examined }\end{array}$} & \multicolumn{2}{|c|}{ Culture and staining method } & \multicolumn{2}{|c|}{ PCR for $E$. coli } \\
\hline & & $\begin{array}{l}\text { No. of gram negative } \\
\text { isolates }\end{array}$ & $\%$ & $\begin{array}{l}\text { No. of } \\
\text { positive }\end{array}$ & $\%$ \\
\hline Jersey Cross bred cows & 31 & 12 & 39 & 6 & 50 \\
\hline Graded Murrah buffaloes & 28 & 13 & 46 & 5 & 39 \\
\hline HF cross & 19 & 7 & 37 & 2 & 29 \\
\hline Total & 78 & 32 & 41 & 13 & 41 \\
\hline
\end{tabular}


Fig.1 Green metallic sheen produced by E. coli (bovine clinical mastitis isolate) on Eosine methylene blue agar

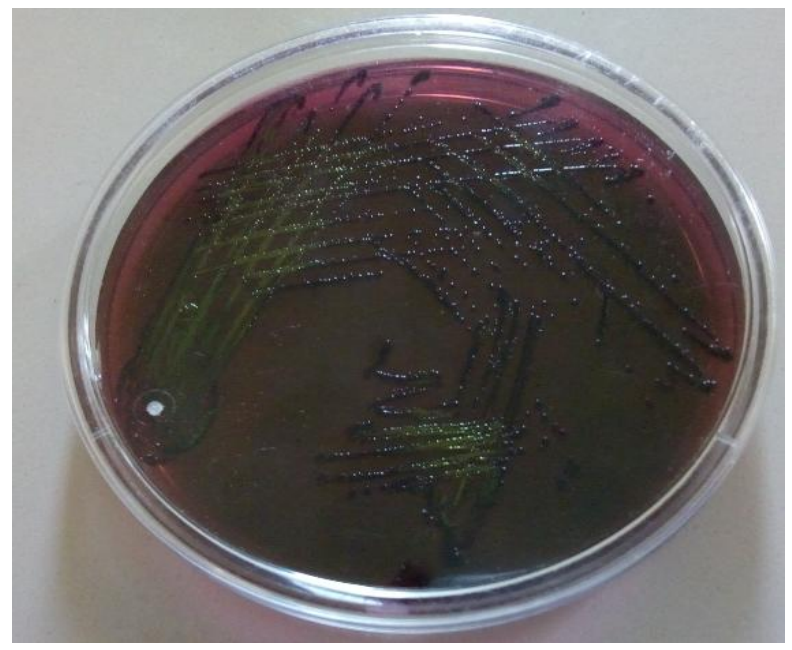

Fig.2 PCR detection of Escherichia coli from field clinical mastitis milk samples. Lane M: 100bp molecular weight marker; Lane 1-9: Clinical mastitis E. coli isolates from field samples; Lane 10: Positive control; Lane 11: Negative control

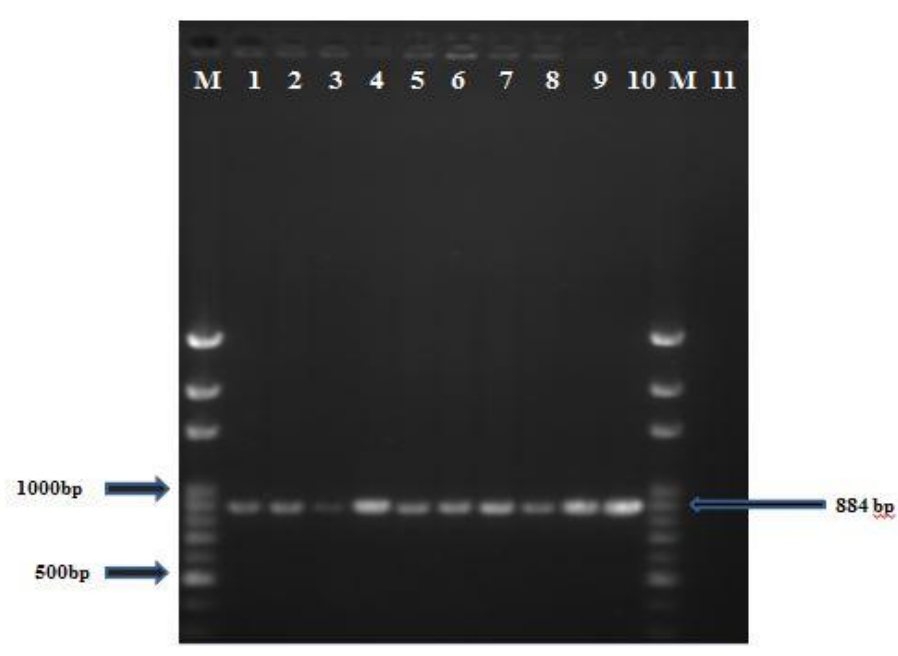

Considering the results of the current investigation and the reviewed data of the various researchers across the globe, the difference in the incidence rates of bovine mastitis caused by E. coli in Jersey and HF cross breeds and graded Murrah buffaloes may be due to variation in the geographical location, size of sampling, macro and micro environment in which the animal resides, size of sampling, sanitary condition of udder, immune status of the animal, cell mediated immune response of the individual breed to E.coli infection (Sadashiva and Kaliwal, 2013, Shopsin et al., 2000 and Sulabh et al., 2019).

In this study, the incidence of bovine clinical mastitis caused by E.coli in various private 
farms in and around Proddatur region of Andhra Pradesh as determined by specific bacteriological culture by growing the gram negative clinical isolates of bovine mastitis on EMB agar and further confirmation by PCR was found to be $41 \%$. Therefore, it can be concluded that E.coli is one of the major causative agent of clinical mastitis in bovines originating from the environment of cow associated with poor sanitation, improper disposal of the farm waste, lack of udder hygiene and most importantly indiscriminate and rampant use of antibiotics ultimately leading to the severe and recurrent mastitis infections, emergence of antibiotic resistant bacteria which can even produce biofilms and persist with in the udder tissue. Hence, there is a need for the screening of dairy herds for the pathogen identification, maintenance of proper hygiene in the farm and related macro environment, nutritional supplementation to reduce the incidence of mastitis and most importantly determining the drug of choice for the treatment by the use of ABST for the successful control of coliform mastitis due to E.coli.

\section{Acknowledgement}

The authors are thankful to Sri Venkateswara Veterinary University, India for providing financial assistance to carry out this research work.

\section{References}

Antony, AC., Mini KP, R Silvester, PA Aneesa, K Suresh, PS Divya, S Paul, PA Fathima and M H Abdulla. 2016. Comparative Evaluation of EMB Agar and Hicrome E. coli Agar for Differentiation of Green Metallic Sheen Producing Non E. coli and Typical E. coli Colonies from Food and Environmental Samples. Journal of Pure and Applied Microbiology.
10(4): $\quad 2863-2870 . \quad$ DOI: 10.22207/JPAM.10.4.48

Biffa, D., E. Debela, and F. Beyene. 2005. Prevalence and risk factors of mastitis in lactating dairy cows in Southern Ethiopia. International Journal of Applied Research in Veterinary Medicine, vol. 3, no. 3, pp. 189-198, 2005.

Bovine mastitis: An Asian perspective, Asian J. Anim. Vet. Adv., 7: 454-476.

Bradley, A.J., M.J., Green, 2001. Adaptation of Escherichia coli to the bovine mammary gland. J. Clin. Microbiol. 39: 1845-1849.

Chen, J., and M.W. Griffiths. 1998. PCR differentiation of Escherichia coli from other gram negative bacteria using primers derived from the nucleotide sequences flanking the gene encoding the universal stress protein. Letters in Applied Microbiology, 27. 369-371

Costa, JCM., I.F. Espeschit, F.A. Pieri et al., Increased production of biofilms by Escherichia coli in the presence of enrofloxacin. Vet Microbiol. 2012. 160. 488.90

Costa, JCM., I.F. Espeschit, F.A. Pieriet al., Increase in biofilm formation by Escherichia coli under conditions that mimic the mastitic mammary gland. Cienc Rural. 2014. 44. 666

Cremonesi, PB., Castiglioni; G. Malferrari, I. Biunno, C. Vimercati, P. Moroni, S. Morandi and M. Luzzana. 2006. Technical Note: Improved Method for Rapid DNA Extraction of Mastitis Pathogens Directly from Milk, J Dairy Sci, 89: 163-169.

Dutta, J., B. S. Rathore, and S. G. Mullick. 1990. Lactational incidence rate of mastitis in exotic and crossbreed cows. An epidemiology study. Indian Journal of Veterinary Pathology, vol. 12, pp. 28-32. 
Iqbal, J and M. Siddique. 1999. Some epidemiological aspects of mastitis in cows and bio-charecterization of isolated Staphylococci. Pakistan Veterinary Journal, vol. 19, no. 3, pp. 149-154, 1999.

Islam N.N, Nur SM, Farzana Z, Uddin I, Kamaruddin KM and Siddiki AMZ. 2014. Rapid Identification of Eosine Methylene Blue Positive Escherichia coli by Specific PCR from Frozen Chicken Rinse in Southern Chittagong City of Bangladesh: Prevalence and Antibiotic Susceptibility. Microbiology Journal, 4: 27-40. DOI: 10.3923/mj.2014.27.40

Litwinczuk Z and JKA Brodziak. 2015. Factors Determining the Susceptibility of Cows to Mastitis and Losses Incurred by Producers Due to the Disease - A Review. Annals of Animal Science 15(4):1-24

Mahantesh M. Kurjogi and B B. Kaliwal. 2014. Epidemiology of Bovine Mastitis in Cows of Dharwad District. International Scholarly Research Notices, 9 pages, 2014. https://doi.org/10.1155/2014/968076.

Mahmoud AKA, AM. Khadr, M Tharwat, Elshemy, A Hassan and HMI Ismail. 2015. Some Studies on E-Coli Mastitis in Cattle and Buffaloes. Alexandria Journal of Veterinary Sciences. 2015, 45: 105-112. DOI: 10.5455/ajvs.178113.

Oviedo-Boyso, J., J.J. Valdez-Alarcon, M. Cajero-Juarez, A. Ochoa-Zarzosa, J.E. Lopez-Meza, A. Bravo-Patino and V.M. Baizabal-Aguirre. 2007. Innate Immune Response of Bovine Mammary Gland to Pathogenic Bacteria Responsible for Mastitis, Journal of Infection. 54: 399-409.

Philip, M., N. Ruben, Gonzalez, J. David, Wilson and R. Hong. 1993. Procedures for mastitis diagnosis and control. In the Vet. Clinics of North America: Food animal practice: Update of bovine mastitis, 9 (3): 445.

Philpot, W.N., and S.C. Nickerson. 1991. Mastitis attack. Surge International Babson Bros. Co. Naperville, Illinois, U.S.A.

Piotrchomczynski and Michal Rymaszewski. 2006. Alkaline polyethylene glycol based method for DNA isolation from bacteria, tissue samples and blood. Biotechniques., 40: 454-458

Radostits, O.M., C.C. Gay, D.C. Blood and K.W. Hinchcliff, 2000. Disease Caused by Bacteria-Mycobacterium. In: Veterinary Medicine: A Text Book of Disease of Cattle, Sheep, Pig, Goat and Horses, Radostits, O.M., C.C. Gay, D.C. Blood and K.W. Hinchcliff (Eds.). 9th Edn. Harcourt Publisher Ltd., London, pp: 909-918

Rahman MA, M. M. U. Bhuiyan, M. M. Kamal, and M. Shamsuddin. 2009. Prevalence and risk factors of mastitis in dairy cows. Bangladesh Veterinarian, vol. 26, no. 2, pp. 54-60

Sadashiv, S. O. and Kaliwal, B. B. (2013): Antibiotic resistance of Staphylococcus aureus and Coagulase negative Staphylococci (CNS) isolated from bovine mastitis in the region of North Karnataka, India. World J. Pharm. Res., 3: 571-586.

Samanta I. 2013. Veterinary Bacteriology. 1st ed. New Delhi, India: New India Publishing Agency

Schukken Y, M. Chuff, P. Moroni, A. Gurjar, C. Santisteban, F. Welcome, R. Zadoks. 2012. The "other" gramnegative bacteria in mastitis: Klebsiella, Serratia, and more. Vet Clin North Am Food Anim Pract. 28(2): 239-56. doi: 10.1016/j.cvfa. 2012.04.001

Seegers. H; C. Fourichon and F. Beaudeau. 2003. Production effects related to 
mastitis and mastitis economics in dairy cattle herds, Vet. Res. 34: 475491.

Sharma N., G.J Rho, Y.H. Hong, T.Y. Kang, H.K. Lee, T.Y. Hur and D.K. Jeong. 2012. Bovine mastitis: An Asian Perspective. Asian J Anim Vet Adv.

Shopsin, B., Mathema, B., Martinez, J. Ha. E., Campo, M. L., Fierman, A., Krasinski, K., Kornblum, J., Alcabes, P., Waddington, M., Riehamn, M. and Kreiswirth, B. N. (2000): Prevalence of methicillin resistant susceptibility of drug resistant Staphylococcus aureus in raw milk of dairy cattle. Int. Res. J. Microbiol., 2: 466-470

Sulabh, S., M. Panigrahi, S. Kumar, R. Varshney, A. Verma, N.A. Baba, J.P. Gupta, A. Chauhan, P. Kumar, T. Dutt and B. Bhushan, 2019. Differential cytokine response of $\mathrm{E}$ coli LPS stimulated PBMCs in crossbred, Tharparkar cattle and Murrah buffalo-
An in vitro study. Spanish Journal of Agricultural Research, Volume 17, Issue 1, e0501

Suriyasathaporn W; C. Heuer; E.N. Noordhuizen-Stassen and Y.H. Schukken. 2000. Hyperketonemia and the Impairment of Udder Defense: $a$ Review. Veterinary Research. 31: 397412.

Vasquez-García A., T.S Silva, S.R. AlmeidaQueiroz, S.H.S. Godoy, A.M. Fernandes, R.L.M. Sousa and R. Franzolin. 2017. Species identification and antimicrobial profile of bacteria causing subclinical mastitis in buffalo. Pesquisa Veterinária Brasileira 37(5): 447-452

Verma H, S Rawat, N Sharma, V Jaiswal and R Singh. 2018. Prevalence, bacterial etiology and antibiotic susceptibility pattern of bovine mastitis in Meerut. Journal of Entomology and Zoology Studies 2018; 6(1): 706-709.

\section{How to cite this article:}

Manasa, V., T. Venkata Sai Kumar, T. Prasada Rao, K. Aswani Kumar and Sireesha, K. 2019. Incidence of Bovine Clinical Mastitis Caused by Escherichia coli. Int.J.Curr.Microbiol.App.Sci. 8(05): 1249-1256. doi: https://doi.org/10.20546/ijcmas.2019.805.142 